\title{
En-Bloc Complete Segment 1 Resection and Left Hepatectomy for Klatskin Tumor
}

\author{
Alexandru Bârcu ${ }^{1,2}$, Alin Kraft ${ }^{1,2}$, Cosmin Verdea ${ }^{2}$, Adina Croitoru ${ }^{3,6}$, Ioana Lupescu ${ }^{4,7}$, Dana Tomescu ${ }^{5,7}$, \\ Irinel Popescu ${ }^{2,6}$, Florin Botea ${ }^{2,6 *}$ \\ 'Doctoral School in Medicine, "Titu Maiorescu" University, Bucharest, Romania \\ ${ }^{2}$ Center of General Surgery and Liver Transplantation, Fundeni Clinical Institute, Bucharest, Romania \\ ${ }^{3}$ Department of Oncology, "Fundeni" Clinical Institute, Bucharest, Romania \\ "Department of Radiology and Imaging, "Fundeni" Clinical Institute, Bucharest, Romania \\ ${ }^{5}$ Department of Intensive Care and Anesthesiology, "Fundeni" Clinical Institute, Bucharest, Romania \\ ${ }^{6}$ Faculty of Medicine, "Titu Maiorescu" University, Bucharest, Romania \\ 7"Carol Davila" University of Medicine and Pharmacy, Bucharest, Romania
}

*Corresponding author:

Florin Botea, MD

Center of General Surgery and Liver Transplantation

Fundeni Clinical Institute

Soseaua Fundeni 258, Bucharest

Romania

E-mail: florinbotea@gmail.com

\section{Rezumat}

Rezecție completă a segmentului 1 în bloc cu hepatectomie stângă pentru tumora Klatskin

Prezentăm cazul unui pacient de sex masculin în vârstă de 37 de ani, fără antecedente patologice semnificative, internat în centrul nostru pentru icter fără durere, cu debut brusc. CT cu contrast a relevat o tumoră localizată la confluența biliară principală, în apropierea bifurcației portale principale, fără invazie vasculară sau metastaze extrahepatice. MRCP a diagnosticat o tumora Klatskin IIIb Bismuth-Corlette. Pentru evaluarea completă a affectării biliare şi a planificării chirurgicale, pe lângă clasificarea BismuthCorlette, am luat în considerare prezența infiltrării canalelor biliare pentru segmentul 1, documentată la MRCP. Prin urmare, o hepatectomie stângă cu rezecție completă a segmentului 1 în bloc, împreună cu calea biliară principală şi limfadenectomie hil hepatic, a fost considerată cea mai potrivită pentru o rezecție curativă în acest caz. După o evoluție postoperatorie fără evenimente, pacientul a fost externat în a 12-a zi postoperatorie. În prezent, pacientul nu prezintă recidivă de boala la 84 de luni postoperator. Considerăm că supraviețuirea fără recidiva pe termen lung a fost favorizată de rezecția completă a segmentului 1. Prin urmare, pentru evaluarea completă a implicării biliare în tumora Klatskin, recomandăm ca, pe lângă clasificarea Bismuth-Corlette, 
să fie evaluată întotdeauna infiltrarea căii biliare pentru segmentul 1. Dacă este prezentă, întregul segment 1 trebuie îndepărtat pentru a obține un rezultat oncologic optim.

Cuvinte cheie: rezecție hepatică, ghidaj prin ecografie intraoperatorie, tumora Klatskin, hemihepatectomie extinsă la întreg segmentul 1

\begin{abstract}
We present the case of a 37-year-old male patient with no significant history, hospitalized in our center for painless jaundice with sudden onset. CT contrast portal phase imaging revealed a tumor located at the main biliary confluence, in the proximity of the main portal bifurcation, with no venous or arterial vascular invasion, nor extrahepatic metastases. MRCP diagnosed a BismuthCorlette type Klatskin IIIb tumor. For complete assessment of biliary involvement and surgical planning, in addition to the Bismuth-Corlette classification, we took into consideration the presence of infiltration of the bile ducts for segment 1, documented at MRCP. Therefore, a left hepatectomy with en-bloc complete segment 1 resection, along with the main bile ducts and hilar lymphadenectomy, was considered best suited for achieving curative resection in this case. After an uneventful postoperative course, the patient was discharged in the $12^{\text {th }}$ postoperative day. Currently, the patient is disease-free after 84 months. We consider that the long-term recurrence free survival was favored by the complete segment 1 resection. Therefore, for complete assessment of biliary involvement in Klatskin tumor, we recommend that in addition to Bismuth-Corlette classification, infiltration of the bile duct for segment 1 should always be evaluated. If present, the entire segment 1 should be removed for best oncological results.
\end{abstract}

Key words: liver resection, intraoperative ultrasound guidance, Klatskin tumor, hemihepatectomy extended to the whole segment 1

\section{Introduction}

Hilar cholangiocarcinoma (CCC), also known as Klatskin tumor, is one of the most challenging tumors to treat due to its aggressiveness and involvement of the most important structures of the liver. It is well known that Bismuth-Corlette, based on the extent of the main hepatic ducts infiltration (common, left and right hepatic ducts), classifies the hilar CCC into 6 types (I, II, IIIa, IIIb, IV and V) $(1,2)$. Currently, this classification is widely used for assessing resectability in such cases. However, it has two main drawbacks: ignores the vascular invasion and does not consider the extent of the disease to the ducts of segment 1. Segment 1, the so-called dorsal lobe of the liver, is located between the main portal pedicles and main trunks of the hepatic veins, anteriorly, and the inferior vena cava (IVC), posteriorly. It is made up by the paracaval portion, on the right, and the Spiegel's (caudate) lobe, on the left. Because of its anatomy and topography, the resection of the entire segment 1 represents a major challenge for a liver surgeon.

\section{Case Report}

We present the case of a 37-year-old athletic male patient, (BMI: 25), without relevant medical and surgical history, hospitalized in our center for a painless jaundice with sudden onset, acholic stools and dark urine. Laboratory tests revealed significant hepatic cytolysis (ALT: $605 \mathrm{U} / \mathrm{ml}$, AST: $150 \mathrm{U} / \mathrm{ml}$ ) and cholestasis (total bilirubinemia $=24,6 \mathrm{mg} / \mathrm{dl}$, direct bilirubinemia $=24,1 \mathrm{mg} / \mathrm{dl}$, AP: 582 
U/ml, GGT: $983 \mathrm{U} / \mathrm{ml}$ ), and onset of renal insufficiency (creatinine: $2.24 \mathrm{mg} / \mathrm{dl}$ ). Tumor markers were within normal range. Contrastenhanced CT-scan portal phase revealed a tumor, of $15 \mathrm{~mm}$ in size, located at the main biliary confluence, in the proximity to the main portal bifurcation, with no venous or arterial vascular invasion, nor extrahepatic metastases. Magnetic resonance cholangiopancreatography revealed a Bismuth-Corlette type Klatskin IIIb tumor, that extends to the emergence of bile ducts for segments 4, 2-3, and infiltrates the duct for segment 1. By means of percutaneous transparietohepatic biliary drainage of the right hemiliver, that targeted the bile duct for segments $5-8$, we managed to significantly decrease the total bilirubinemia (to $6,4 \mathrm{mg} / \mathrm{dl}$ in the $8^{\text {th }}$ postprocedural day), preventing cholangitis.

In addition to the Bismuth-Corlette classification, when we considered the surgical planning, we also took into consideration that the dilated bile duct for segment 1 showed signs of neoplasic infiltration, therefore we decided that a left hemihepatectomy with enbloc resection of the entire segment 1 (of both the caudate lobe and the paracaval portion), along with the common bile duct resection and hilar lymphadenectomy, was best suited in order to achieve curative resection in this particular case.

First key step consisted in the complete liver mobilization and cholecystectomy, followed by hilar dissection and lymphadenectomy. Next, the left hepatic artery and left portal vein were sectioned, while the right hepatic duct was left to be sectioned during the parenchymal transection. The vessels supplying the future remnant liver, represented by the right hemiliver (the right hepatic artery and portal vein) were carefully preserved. The second key step consisted in transection of the liver parenchyma along the Cantlie's line until the middle hepatic vein was exposed and preserved. At this point, the right hepatic duct was sectioned at the confluence of the bile ducts for segments 6-7 and for segments 5-8. Samples were taken from the remnant biliary stump and analyzed using frozen sections, documenting the
R0 resection at this level. The third key step consisted in shifting the parenchymal transection to the right: with the liver previously fully mobilized from inferior vena cava, we redirected the transection plane towards right, guiding it to pass below the middle and right hepatic veins. To follow this plane, we applied a reversed hanging maneuver as demonstrated, using a silicone band, an innovative technical trick that proved very effective. Liver transection was carried out using Pean-clasia. A tourniquet was placed on the hilum, but Pringle manouvre was not considered necessary. The biliary reconstruction was done using a Roux-en-Y cholangiojejunostomy.

\section{Results}

The operative time was $340 \mathrm{~min}$. There were no intraoperative incidents. Blood losses counted for $800 \mathrm{ml}$, with no blood transfusion needed. The postoperative course was marked by mild ascites that responded well to conservative treatment. The patient was discharged in the 12th postoperative day. Histology and immunohistochemistry showed a well differentiated G1 cholangio-adenocarcinoma (tubular and microglandular adenocarcinoma), R0 resection margin status pT2pN1 (1 tumoral lymph node out of the 9 harvested). Oncological treatment consisted in adjuvant chemotherapy with Gemcitabine. Currently, the patient is disease-free at 84 months surgery.

\section{Discussion}

Due to its relation to the main hepatic duct confluence (HDC), in most cases of hilar CCC, the biliary ducts draining $\mathrm{S} 1$ are also invaded (3-5), with an incidence of $31-98 \%(5,6)$, and complete en-bloc resection should be performed in these cases for curative surgery (79). Many other factors should be taken into account when assessing liver resectability, considering the predominant side of the tumor, the length of the left and right hepatic ducts, the hepatic distribution of the bile ducts, the relationship with the portal and 
arterial branches, and the vasculo-biliary anatomical variants (10). Partial segment 1 resection, especially involving the caudate lobe, is easier to achieve but involves higher risk of recurrence (6). Even though complete resection has a lower risk of recurrence, still the 5-year overall survival rate varies between 15 to $35 \%$ (11) due to high biological aggressiveness of this type of tumor. Thereby, hemihepatectomy with complete segment 1 resection has been accepted as a method of choice in the surgical treatment of hilar CCC (12).

While for the caudate lobe, anatomical landmarks almost always suffice for establishing the resection plane, for the boundary between the right posterior section and the paracaval portion of segment 1 additional methods are necessary. In this sense, coloration technique (i.e., methylene blue staining), (13) or the use of indocyanine-green fluorescence (14) depicts one of the two neighbors on the boundary (segment 1 - staining method, or segments 6-7 - counterstaining method) facilitating the resection of $\mathrm{S} 1$. The alternative is the use of intraoperative ultrasound guidance that can easily and effectively depict the boundary of segment 1 . Moreover, the use of the reversed hanging maneuver described in our video, further facilitate transection at this level. De Lu et al. (15) reported 8 cases with total hilar en bloc resection with left hemihepatectomy and segment 1 resection, and portal vein and hepatic artery reconstruction.

Despite its current benefits and expanding applications (11), laparoscopic approach for hilar CCC is rarely chosen, in carefully selected patients, mainly due to the technical complexity involved $(4,11,16)$. However, various such cases have been reported with favorable outcomes, for all Bismuth types $(3,11,17,18)$. Particularly, Zhang et al. (17) reported one case with successful extended right hemihepatectomy with resection of segment 1 . The average rate of morbidity in laparoscopic approach is about $38.9 \%$, while being less in case of Bismuth type I and II tumors (16).

$\mathrm{S} 1$ resection is associated with a longer operating time and an increased blood loss, with a higher risk of postoperative complications (2). It was reported that high preoperative levels of serum bilirubin is correlated with higher risk of postoperative death (19). Jaundice involves a higher risk of bleedings, biliary leakage, liver failure and sepsis, leading to increased morbidity and mortality rates $(5,19)$. Therefore, it is recommended to perform interventional biliary drainage prior to surgery.

In high-volume centers, the operative mortality of hemihepatectomy with $\mathrm{S} 1$ resec- $^{-}$ tion has decreased to about 5\% (20), with a better mean survival when compared with hemihepatectomy without $\mathrm{S} 1$ resection (30 to 64 months vs 17 to 35 months) (21). De Lu et al. (11) reported the longest survival of 50 months. Rea et al. (22) argue that liver transplantation should be preferred over hepatectomy with S1 resection; however liver transplantation may be offered only in highly selected patients (23).

There are several alternatives to hemihepatectomy with complete $\mathrm{S} 1$ resection. The isolated segment 1 resection with bile duct resection is not recommended because of the technical difficulty and high risks associated with the reconstruction of the biliary ducts (24). Resection of segments 1, 4 inferior and 5 with bile duct resection, the also called the "Taj Mahal" resection, offers better approach for the S1 resection and for the biliary reconstruction. Hwang et al recommends the resection of segments 1 and 4, that provides a wide operative field for the bile ducts resection and reconstruction. Depending on the degree of invasion, the resection may be extended nonanatomically to segment 5 and/or 8 . However, vascular reconstruction is not recommended when using this approach as exposes to high risk of complications (24). Moreover, Japanese surgeons favor the extended left hepatectomy, because it insures more often a radical resection. Conversely, European surgeons prefer right hepatectomy, as it complies with the "notouch" technique $(25,26)$. The advantages and disadvantages of a right or left hepatectomy are under debate. Resection of the liver segments 1, 2, 3 and 4 (called H1234 by the 
recent "New World" terminology) may be a better option than an extended right hepatectomy, because segment 4 is anatomically included in the left hemiliver, and involves a larger remnant volume (10).

In conclusion, despite the risks, hemihepatectomy with complete $\mathrm{S} 1$ resection performed in high-volume HPB center assures optimal oncological outcomes in patients with hilar CCC. Given the current disease-free survival of 84 months, for complete assessment of biliary involvement in Klatskin tumor, we recommend that in addition to BismuthCorlette classification, infiltration of the bile duct for segment 1 should always be evaluated. If present, the entire segment 1 should be removed for best oncological results.

\section{Acknowledgements}

This paper is part of a $\mathrm{PhD}$ thesis, currently under development by Alexandru Barcu MD, $\mathrm{PhD}$ student, entitled "Intraoperative ultrasound in liver resection for colorectal metastases" (Medical Doctoral School, IOSUD Titu Maiorescu University of Bucharest).

\section{Conflict of Interest}

The authors declare no conflicts of interests.

\section{Ethics Approval}

All procedures performed were in accordance with the ethical standards of the 1964 Helsinki Declaration.

\section{References}

1. Mercado MA, Domínguez I. Classification and management of bile duct injuries. World J Gastrointest Surg. 2011;3(4):43-8.

2. Hu HJ, Mao H, Shrestha A, Tan YQ, Ma WJ, Yang Q, et al. Prognostic factors and long-term outcomes of hilar cholangiocarcinoma: A singleinstitution experience in China. World J Gastroenterol. 2016;22(8):2601-10.

3. Rahnemai-Azar AA, Abbasi A, Tsilimigras DI, Weber SM, Pawlik TM Current Advances in Minimally Invasive Surgical Management of Perihilar Cholangiocarcinoma. J Gastrointest Surg. 2020;24(9):2143-9.

4. Lee W, Han HS, Yoon YS, Cho JY, Choi Y, Shin HK, et al. Laparoscopic resection of hilar cholangiocarcinoma. Ann Surg Treat Res. 2015;89(4): 228-32

5. Yang M, Li WW, Chen JH, Cui MH, Liu JL. The value of caudate lobectomy in hilar cholangiocarcinoma treatment: A meta-analysis. Medicine (Baltimore). 2021:100(7):e24727.

6. Chaib E, Ribeiro MA, Silva FeS, Saad WA, Cecconello I. Surgical approach for hepatic caudate lobectomy: Review of 401 cases. J Am Coll Surg. 2007; 204(1):118-27

7. Dinant S, Gerhards MF, Busch OR, Obertop H, Gouma DJ, Van Gulik TM. The importance of complete excision of the caudate lobe in resection of hilar cholangiocarcinoma. HPB (Oxford). 2005;7(4):263-7.

8. Perini MV, Coelho FF, Kruger JA, Rocha FG, Herman P. Extended right hepatectomy with caudate lobe resection using the hilar "en bloc" resection technique with a modified hanging maneuver. J Surg Oncol. 2016;113(4): 427-31.

9. Neuhaus P, Thelen A, Jonas S, Puhl G, Denecke T, Veltzke-Schlieker W, et al. Oncological superiority of hilar en bloc resection for the treatment of hilar cholangiocarcinoma. Ann Surg Oncol. 2012;19(5):1602-8.

10. Lang H, van Gulik TM. Extended Right-hemihepatectomy Is Preferred for Perihilar Cholangiocarcinoma. Ann Surg. 2021;274(1):33-4

11. Li J, Zhao L, Zhang J, Li Z, Li A, Wei Y, et al. Application of the laparoscopic technique in perihilar cholangiocarcinoma surgery. Int J Surg. 2017:44:104-9.

12. Hong SS, Han DH, Choi GH, Choi JS. Comparison study for surgical outcomes of right versus left side hemihepatectomy to treat hilar cholangiocellular carcinoma. Ann Surg Treat Res. 2020:98(1):15-22.

13. Chen JY, Cai SW, Liu ZW, Xing XL. Left hepatectomy with caudate lobe resection using the methylene blue staining technique for bismuth IIIb hilar cholangiocarcinoma. Hepatobiliary Surg Nutr. 2019;8(6):674-6.

14. Nakaseko Y, Ishizawa T, Saiura A. Fluorescence-guided surgery for liver tumors. J Surg Oncol. 2018;118(2):324-31

15. De Lu C, Huang J, Wu SD, Hua YF, Javed AA, Fang JZ, et al. Total Hilar En Bloc Resection with Left Hemihepatectomy and Caudate Lobectomy: a Novel Approach for Treatment of Left-Sided Perihilar Cholangiocarcinoma (with Video). J Gastrointest Surg. 2017;21(11):1906-14.

16. Hu HJ, Wu ZR, Jin YW, Ma WJ, Yang Q, Wang JK, et al. Minimally invasive surgery for hilar cholangiocarcinoma: state of art and future perspectives. ANZ J Surg. 2019;89(5):476-80.

17. Zhang CW, Liu J, Hong DF, Wang ZF, Hu ZM, Huang DS, et al. Pure laparoscopic radical resection for type Illa hilar cholangiocarcinoma. Surg Endosc. 2018:32(3):1581-2

18. Liu S, Liu X, Li X, Li O, Yi W, Khan J, et al. Application of Laparoscopic Radical Resection for Type III and IV Hilar Cholangiocarcinoma Treatment. Gastroenterol Res Pract. 2020;2020:1506275.

19. Ribero D, Zimmitti G, Aloia TA, Shindoh J, Fabio F, Amisano M, et al. Preoperative Cholangitis and Future Liver Remnant Volume Determine the Risk of Liver Failure in Patients Undergoing Resection for Hilar Cholangiocarcinoma. J Am Coll Surg. 2016;223(1):87-97.

20. Endo I, Matsuyama R, Taniguchi K, Sugita M, Takeda K, Tanaka K, et al. Right hepatectomy with resection of caudate lobe and extrahepatic bile duct for hilar cholangiocarcinoma. J Hepatobiliary Pancreat Sci. 2012;19(3): 216-24.

21. Birgin $E$, Rasbach $E$, Reissfelder C, Rahbari NN. A systematic review and meta-analysis of caudate lobectomy for treatment of hilar cholangiocarcinoma. Eur J Surg Oncol. 2020;46(5):747-53.

22. Rea DJ, Heimbach JK, Rosen CB, Haddock MG, Alberts SR, Kremers WK, et al. Liver transplantation with neoadjuvant chemoradiation is more effective than resection for hilar cholangiocarcinoma. Ann Surg. 2005:242(3):451-8; discussion 8-61.

23. Heimbach JK, Haddock MG, Alberts SR, Nyberg SL, Ishitani MB, Rosen CB, et al. Transplantation for hilar cholangiocarcinoma. Liver Transpl. 2004;10(10 Suppl 2):S65-8.

24. Hwang S. Standard and modified techniques for parenchyma-preserving hepatectomy focused on segments I+IV resection in patients with perihilar cholangiocarcinoma. Ann Hepatobiliary Pancreat Surg. 2021;25(1):112-21.

25. Donati M, Stang A, Stavrou GA, Basile F, Oldhafer KJ. Extending resectability of hilar cholangiocarcinomas: how can it be assessed and improved? Future Oncol. 2019;15(2):193-205.

26. Liu CL, Fan ST. Anterior approach for right hepatectomy for hilar cholangiocarcinoma. J Hepatobiliary Pancreat Surg. 2003;10(4):292-4. 